\title{
PERANCANGAN ALAT PENGGEMBUR TANAH UNTUK PETANI PALAWIJA (Studi Kasus pada Desa KubuColia Kabupaten Karo)
}

\author{
Meilita Tryana Sembiring ${ }^{1}$, Dini Wahyuni ${ }^{2}$, Indah Rizkya Tarigan ${ }^{3}$. \\ ${ }^{123}$ Fakultas Teknik, Universitas Sumatera Utara \\ email: meilita_tryana@yahoo.co.id \\ ${ }^{2}$ email: diniwahyuni2015@gmail.com \\ 3email: indahrizkya@gmail.com
}

\begin{abstract}
Kenyamanan kerja merupakan penunjang untuk meningkatkan produktivitas. Untuk menunjang kenyamanan kerja maka diperlukan alat penunjang kerja yang ergonomis dan sesuai dengan dimensi tubuh operator. Studi yang berhubungan dengan pengukuran dimensi tubuh manusia sebagai pertimbangan ergonomis dalam proses perancangan dikenal dengan istilah antropometri. Pada kegiatan pengabdian kepada masyarakat ini dilakukan perancangan alat penggembur tanah untuk meningkatkan produktivitas petani palawija di desa Kubucolia Kabupaten Karo yang sesuai dengan dimensi tubuh operator. Pengambilan dimensi tubuh pada operator dilakukan dengan cara mengambil sampling dimensi tubuh yang akan digunakan utnuk perancangan alat penggembur tanah seperti Lebar Bahu (LB), Jangkauan Tangan (JT), Tinggi Siku Berdiri (TSB) dan Diameter Genggam (DG). Hasil yang diperoleh adalah mengetahui dimensi tubuh yang akan digunakan dalam perancangan alat penggembur tanah pada Pertanian Palawija desa Kubucolia Kabupaten Karo yaitu menggunakan dimensi Lebar Bahu (LB) sebesar 45,79 cm, Jangkauan Tangan (JT) sebesar 67,26 $\mathrm{cm}$, Tinggi Siku Berdiri (TSB) sebesar 90,83 cm dan Diameter Genggam (DG) sebesar 3,40 cm.
\end{abstract}

Keywords : Alat Penggembur Tanah, Ergonomis, Antropometri, Pertanian Palawija

\section{PENDAHULUAN}

Tanaman palawija di Sumatera Utara cukup potensial. Beberapa tanaman palawija yang banyak dihasilkan Provinsi Sumatera Utara adalah jagung, kacang tanah, kacang kedelai, kacang hijau, ubi kayu, ubi jalar, dll. Produksi jagung Sumatera Utara tahun 2010 sebesar 1.377 .718 ton, naik sebesar 67.579 ton atau 18,10 persen dibandingkan produksi jagung tahun 2009 yakni sebesar 1.166.548 ton. Produksi ubi jalar Sumatera Utara tahun 2010 sebesar 179.387 ton, naik sebesar 39.249 ton atau 28,01 persen dibandingkan produksi ubi jalar tahun 2009. Namun untuk produksi kacang-kacangan seperti kacang tanah, kacang kedelai, dan kacang hijau dan ubi kayu mengalami penurunan. Hal ini dikarenakan menurunnya jumlah lahan dan produktivitas petani.

Perkembangan pertanian di Indonesia khususnya di Sumatera Utara tidak terlepas dari peran kelompok tani. Kelompok tani adalah beberapa orang petani yang menghimpun diri dalam suatu kelompok karena memiliki keserasian dalam tujuan, motif, dan minat. Kelompok tani dapat memainkan peran tunggal maupun ganda, seperti penyediaan input usaha tani, penyediaan air irigasi, penyediaan modal, penyediaan informasi, serta pemasaran hasil secara kolektif.

Kelompok tani memiliki peran yang sangat penting terhadap peningkatan produktivitas lahan para anggotanya. Kelompok tani juga banyak memberikan informasi dan bantuan teknologi maupun metode kerja bagi para anggota untuk meningkatkan produktivitas. Di Sumatera Utara sangat banyak kelompok tani yang terbentuk terutama di daerah-daerah yang menggantungkan hidupnya dari hasil pertanian seperti Kabupaten Karo. Kabupaten ini merupakan daerah yang banyak menghasilkan hasil pertanian. Bahkan produksi jagung tertinggi di Sumatera Utara adalah Kabupaten Karo.

Di kabupaten Karo terdapat salah satu Gabungan Kelompok Tani yaitu Gapoktan Sada Perarih. Gapoktan Sada Perarih berada di Desa Kubucolia Kecamatan Dolat Kabupaten Karo dengan beranggotak sekitar 13 kelompok tani. Jumlah lahan yang tergabung dalam Gapoktan Sada Perarih ini sekitar 54 Hektar. Kelompok tani ini belum benar-benar mampu meningkatkan produktivitas. Beberapa dari poktan masih 
Tryana, M. et al. Perancangan Alat Penggembur Tanah Untuk Petani Palawija

menggunakan peralatan pertanian sederhana terutama pada penggemburan tanah. Proses penggemburan tanah dilakukan dengan peralatan cangkul, sekop, garu, dll. Meskipun beberapa poktan yang memiliki dana yang cukup sudah menggunakan peralatan pertanian yang lebih baik. Penggemburan tanah dengan peralatan sederhana tersebut menyebabkan proses penggarapan lahan menjadi lambat. Kualitas tanah gemburan juga kurang baik karena masih banyak terdapat bongkahan tanah yang dipecahkan.

Selama ini para petani gapoktan Sada Perarih melakukan proses penggemburan tanah dengan peralatan sederhana seperti cangkul, sekop dan garu/harrow. Cangkul dan sekop masih menghasilkan bongkahanbongkahan tanah yang kemudian dihancur menggunakan garu/harrow. Dengan menggunakan peralatan sederhana tersebut proses penggemburan tanah menjadi berulang yaitu di cangkul terlebih dahulu lalu dihancurkan dengan garu. Pekerjaan ini menyebabkan konsumsi waktu yang banyak sehingga jumlah lahan yang dapat digarap tidak besar.

Cara penggemburan tanah saat ini hanya mampu menyelesaikan $200 \mathrm{~m}^{2}$ hingga $250 \mathrm{~m}^{2}$ dalam satu hari. Untuk menyelesaikan lahan yang luas maka membutuhkan pekerja tambahan sehingga proses penggemburan tanah dapat selesai dengan cepat.

Penggunaan peralatan sederhana seperti cangkul, garu, sekop kurang aman untuk petani karena pengoperasian yang manual dan tanpa adanya pelindung terkadang dapat melukai petani. Disamping itu penggunaan peralatan sederhana juga dapat menyebabkan tingkat kelelahan pekerja meningkat karena kerja otot yang begitu besar dan postur kerja yang tidak ergonomis. Postur kerja menggunakan peralatan yang ada saat ini dilakukan dengan membungkuk, dapat dilihat pada Gambar 1.

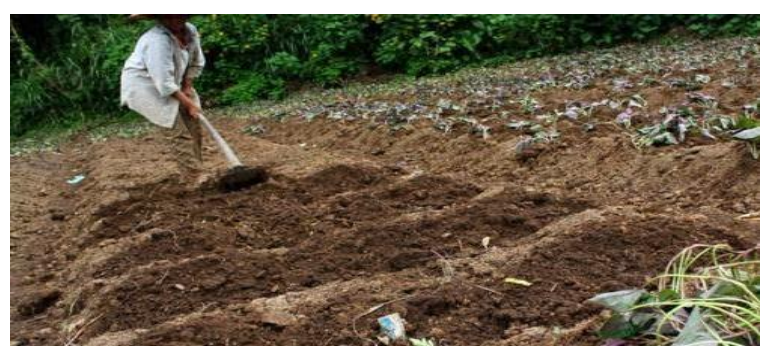

Gambar 1. Proses Penggemburan Tanah di Desa Kubucolia Kabupaten Karo
Pekerjaan yang dilakukan dengan membungkuk menyebabkan kelelahan kerja yang tinggi karena posisi tubuh tidak sempurna dan tulang punggung dan leher menahan beban yang tinggi.

\section{TARGET DAN LUARAN \\ 2.1. Target}

Kegiatan pengabdian ini memiliki target untuk menghasilkan produk yang dapat membantu petani dalam penggemburan sekaligus perataan tanah sebelum dilakukan pembibitan. Penggemburan dan perataan tanah dengan cara manual yang selama ini dilakukan membutuhkan waktu dan tenaga kerja yang banyak sehingga dengan menggunakan alat bantu penggemburan dan perataan tanah dapat meningkatkan efisiensi dan produktivitas penggarapan lahan.

\subsection{Luaran}

Target Luaran dari kegiatan pengabdian ini adalah merancang sebuah alat penggembur dan perata tanah yang dapat membantu dan memudahkan masyarakat dalam proses penggemburan dan perataan tanah pada penanaman palawija.

\section{METODE PELAKSANAAN}

Bagan alir pelaksanaan program pengembangan teknologi penggembur dan perata tanah dapat dilihat pada Gambar 2 di bawah ini.

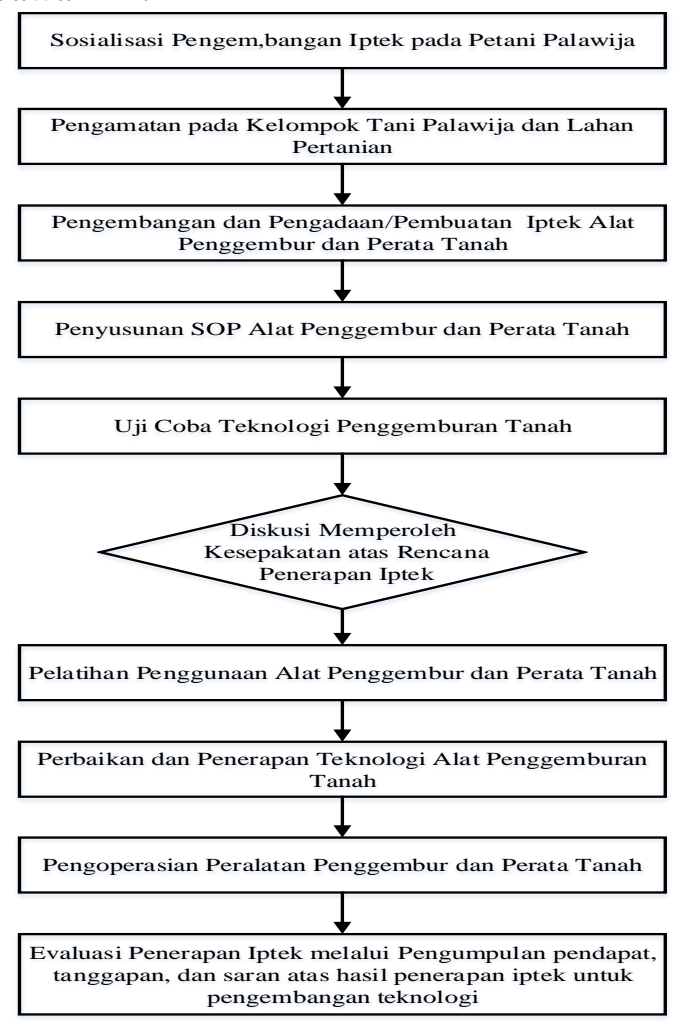


Tryana, M. et al. Perancangan Alat Penggembur Tanah Untuk Petani Palawija

Gambar 2. Bagan Alir Pelaksanan Pengabdian Penerapan Iptek

\section{HASIL DAN PEMBAHASAN}

\subsection{Sosialisasi Pengembangan Iptek}

Pada tahap ini dilakukan sosialisasi kepada petani palawija tentang tujuan dari diadakannya pengabdian kepada masyarakat di desa Kubucolia Kabupaten Karo dan menjelaskan mengenai pemanfaatan iptek untuk mempermudah petani dalam melakukan proses penanaman.

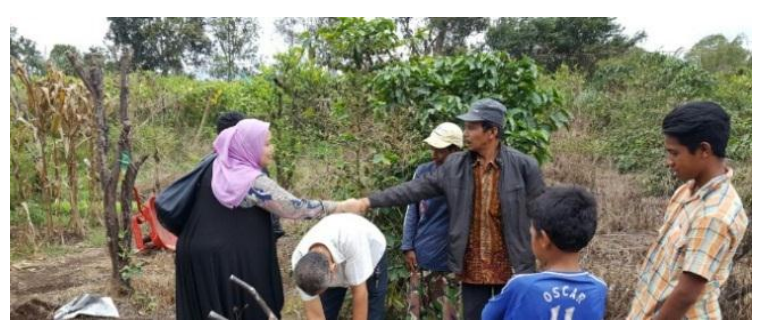

Gambar 3. Sosialisasi Kepada Petani Palawija Desa Kubucolia Kabupaten Karo

\subsection{Pengamatan pada Kelompok Tani}

Pada tahap ini dilakukan pengamatan langsung kepada Kelompok Tani di desa Kubucolia Kabupaten Karo utnuk mengetahui kondisi lokasi pengabdian.

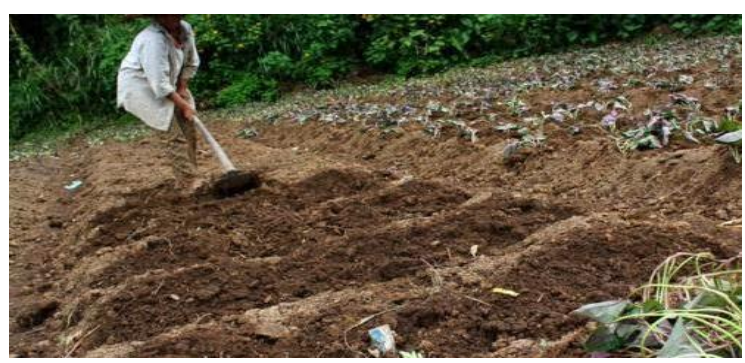

Gambar 4. Pengamatan Lahan Pertanian Kelompok Tani Desa Kubucolia Kabupaten Karo

\subsection{Perancangan Alat Penggembur Tanah}

Penerapan iptek yang akan dilakukan pada pengabdian ini adalah melakukan perancangan alat penggembur tanah yang dapat memudahkan para petani palawija dalam melakukan penggemburan tanah. Prinsip yang digunakan dalam melakukan perancangan alat ini adalah menggunakan prinsip Antropometri.

Dimensi yang digunakan dalam melakukan perancangan alat penggembur tanah dapat dilihat pada Tabel 1 .
Tabel 1. Dimensi Tubuh dan Persentil

\begin{tabular}{|c|l|l|c|}
\hline $\begin{array}{c}\text { Dimen } \\
\text { si }\end{array}$ & $\begin{array}{c}\text { Keteranga } \\
\text { n }\end{array}$ & \multicolumn{1}{|c|}{$\begin{array}{c}\text { Dimensi } \\
\text { Alat }\end{array}$} & $\begin{array}{c}\text { Persent } \\
\text { il }\end{array}$ \\
\hline LB & Lebar Bahu & $\begin{array}{l}\text { Lebar antara } \\
\text { kedua } \\
\text { pegangan } \\
\text { alat }\end{array}$ & 95 th \\
\hline JT & $\begin{array}{l}\text { Jangkauan } \\
\text { Tangan }\end{array}$ & $\begin{array}{l}\text { Jarak antara } \\
\text { tuas dengan } \\
\text { pegangan } \\
\text { alat }\end{array}$ & 5 th \\
\hline TSB & $\begin{array}{l}\text { Tinggi } \\
\text { Siku } \\
\text { Berdiri }\end{array}$ & $\begin{array}{l}\text { Tinggi dari } \\
\text { roda sampai } \\
\text { pegangan } \\
\text { alat }\end{array}$ & 5 th \\
\hline DG & $\begin{array}{l}\text { Diameter } \\
\text { Genggam }\end{array}$ & $\begin{array}{l}\text { Diameter } \\
\text { pegangan } \\
\text { alat }\end{array}$ & 5 th \\
\hline
\end{tabular}

Data antropometri yang digunakan dalam perancangan alat penggembur tanah ini diperoleh dari Laboratorium Ergonomi \& Perancangan Sistem Kerja Departemen Teknik Industri Fakultas Teknik Universitas Sumatera Utara.

Setelah diperoleh data anthropometri, selanjutnya akan ditentukan nilai persentil. Nilai persentil yang dicari adalah nilai persentil 5 dan 95. Nilai-nilai persentil ke-5 dan 95 untuk seluruh dimensi anthropometri dapat dilihat pada Tabel 2.

Tabel 2. Perhitungan Persentil untuk Seluruh Dimensi Anthropometri

\begin{tabular}{|c|c|c|c|c|c|}
\hline $\begin{array}{l}\text { Di } \\
\text { me } \\
\text { nsi }\end{array}$ & $\begin{array}{c}\text { Ketera } \\
\text { ngan }\end{array}$ & $\begin{array}{c}\text { Rat } \\
\text { a- } \\
\text { rata }\end{array}$ & $\mathbf{S}$ & $\begin{array}{c}\text { Persen } \\
\text { til }\end{array}$ & $\begin{array}{l}\text { Ukura } \\
\text { n (cm) }\end{array}$ \\
\hline LB & $\begin{array}{l}\text { Lebar } \\
\text { Bahu }\end{array}$ & 40,5 & $\begin{array}{c}5,7 \\
4\end{array}$ & 95 th & $\begin{array}{c}45,785 \\
6\end{array}$ \\
\hline JT & $\begin{array}{l}\text { Jangka } \\
\text { uan } \\
\text { Tangan }\end{array}$ & 76,4 & $\begin{array}{c}5,9 \\
6\end{array}$ & 5 th & $\begin{array}{c}67,261 \\
1\end{array}$ \\
\hline $\begin{array}{c}\text { TS } \\
\text { B }\end{array}$ & $\begin{array}{c}\text { Tinggi } \\
\text { Siku } \\
\text { Berdiri }\end{array}$ & $\begin{array}{c}101 \\
1\end{array}$ & $\begin{array}{c}7,6 \\
6\end{array}$ & 5 th & $\begin{array}{c}90,827 \\
4\end{array}$ \\
\hline $\mathrm{DG}$ & $\begin{array}{l}\text { Diamet } \\
\text { er } \\
\text { Gengga } \\
\text { m }\end{array}$ & 4,36 & $\begin{array}{c}0,7 \\
3\end{array}$ & 5 th & $\begin{array}{c}3,3964 \\
2\end{array}$ \\
\hline
\end{tabular}

Data antropometri/dimensi tubuh yang ada akan digunakan sebagai data untuk perancangan peralatan. Tiga prinsip antropometri yang digunakan dalam 
perancangan suatu produk adalah:

1. Prinsip penggunaan data antropometri yang ekstrim

2. Prinsip penggunaan data antropometri rata-rata

3. Prinsip penggunaan data antropometri yang dapat disesuaikan

Pengolahan data untuk menentukan dimensi alat penggembur tanah ini menggunakan prinsip penggunaan data anthropometri yang ekstrim dengan tujuan hasil rancangan dapat digunakan dengan nyaman oleh populasi yang ada. Hasil pengolahan data untuk menentukan dimensi rancangan fasilitas kerja adalah sebagai berikut:

1. Data mengenai diameter genggam (DG) digunakan untuk menentukan diameter pegangan alat penggembur dan perata tanah. Prinsip yang digunakan dalam perhitungan diameter genggam adalah prinsip ekstrim bawah. Berdasarkan prinsip tersebut, perhitungan lebar bahu dilakukan dengan menghitung persentil 5, yakni sebesar 3,39642 cm.

2. Data mengenai jangkauan tangan (JT) digunakan untuk menentukan jarak antara tuas dengan pegangan pada alat penggembur dan perata tanah. Prinsip yang digunakan dalam perhitungan jangkauan tangan antara kedua pegangan alat adalah prinsip ekstrim bawah. Berdasarkan prinsip tersebut, perhitungan jangkauan tangan dilakukan dengan menghitung persentil 5, yakni sebesar $67,2611 \mathrm{~cm}$.

3. Data mengenai lebar bahu (LB) digunakan untuk menentukan lebar antara kedua pegangan pada alat penggembur dan perata tanah. Prinsip yang digunakan dalam perhitungan lebar antara kedua pegangan alat adalah prinsip ekstrim atas. Berdasarkan prinsip tersebut, perhitungan lebar bahu dilakukan dengan menggunakan persentil 95, yakni sebesar $45,7856 \mathrm{~cm}$.

Data mengenai tinggi siku berdiri (TSB) digunakan untuk menentukan tinggi dari roda sampai kepada. Prinsip yang digunakan dalam perhitungan tinggi siku berdiri antara kedua pegangan alat adalah prinsip ekstrim bawah. Berdasarkan prinsip tersebut, perhitungan lebar bahu dilakukan dengan menghitung persentil 5, yakni sebesar $90,8274 \mathrm{~cm}$.

\subsection{Hasil Perancangan Alat}

Hasil rancangan dari alat penggembur tanah dapat dilihat pada Gambar 5.

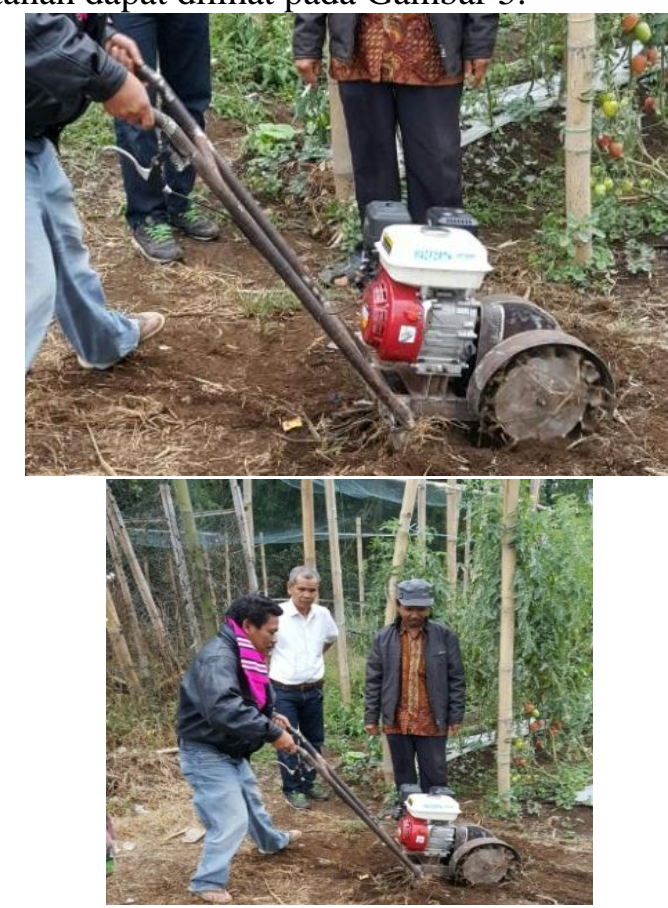
Gambar 5. Hasil Rancangan Alat
Penggembur Tanah

\subsection{Standard Operation Procedure Penggunaan Alat}

Adapun aturan pakai atau cara penggunaan alat penggembur tanah ini adalah sebagai berikut.

1. Pastikan bahan bakar pada alat masih mencukupi.

2. Pastikan tuas berada pada posisi OFF.

3. Pindahkan tuas ke posisi ON.

4. Tarik tali penghidup mesin.

5. Pegang handle mesin.

6. Jalankan mesin ke tanah yang akan digemburkan.

7. Untuk menambah kecepatan dapat mnekan handle pada bagian kanan mesin. 


\subsection{Uji Coba Alat Penggembur Tanah}

Pada tahap ini dilakukan uji coba pada alat penggembur tanah yang dapat dilihat pada Gambar 6.

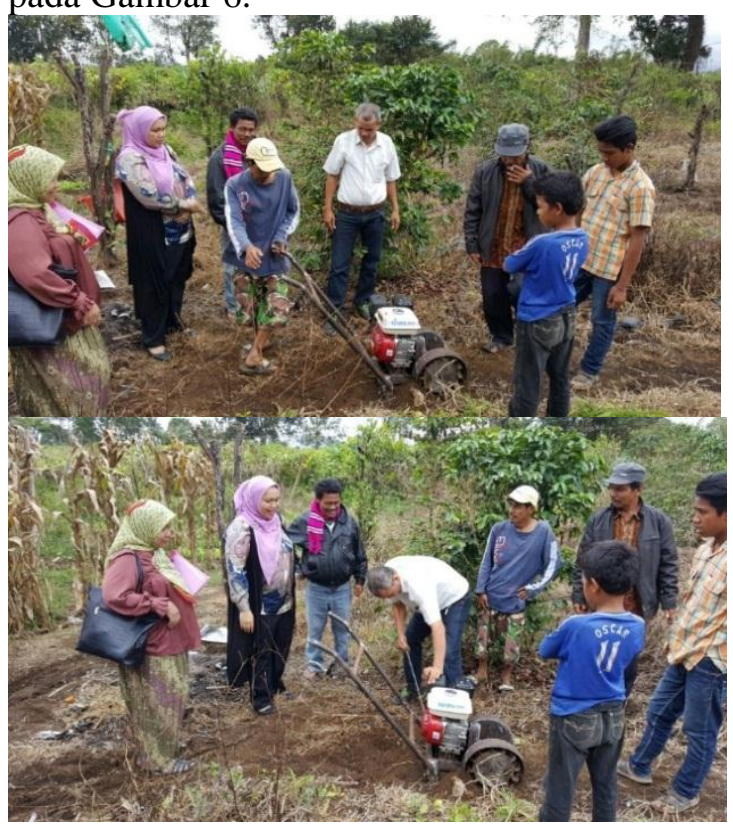

Gambar 6. Uji Coba Alat Penggembur Tanah

\subsection{Pelatihan dan Pengoperasian Alat Penggembur Tanah}

Pada tahap ini dilakukan pelatihan kepada para petani palawija untuk menggunakan alat penggembur tanah sekaligus pengoperasian alat yang dapat dilihat pada Gambar 7 .

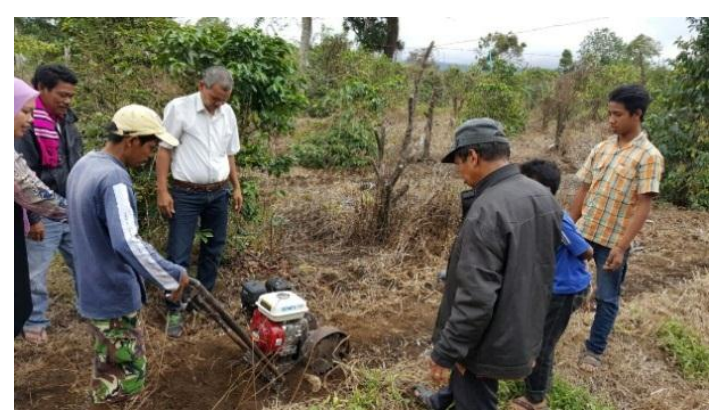

Gambar 7. Pelatihan dan Pengoperasian Alat Penggembur Tanah

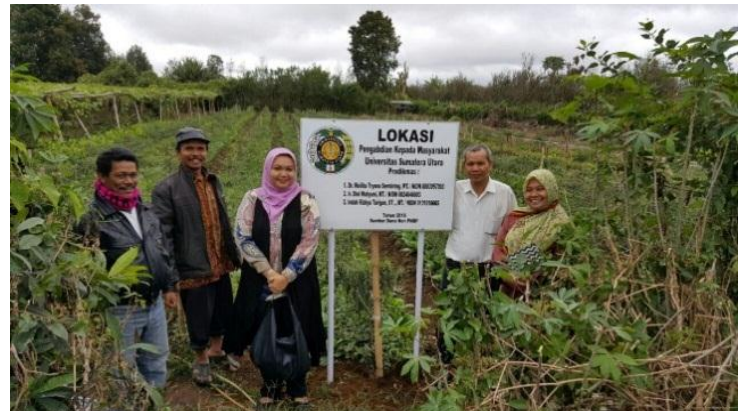

Gambar 8. Plang Lokasi Pengabdian

\section{KESIMPULAN}

Dari hasil pelaksanaan kegiatan pengabdian ini dapat ditarik kesimpulan sebagai berikut:

1. Pelaksanaan kegiatan pengabdian berkalan lancer dan berhasil memberikan manfaat bagi masyarakat sasaran.

2. Pengadaan Alat Penggembur Tanah dapat mempermudah proses penggemburan tanah bagi para petani palawija desa Kubucolia Kabupaten Karo.

\section{DAFTAR PUSTAKA}

Blankchard, Benjamin \& Walter J. Fabrycky. 1998. System Engineering and Analysis. Edisi Ketiga. New Jersey :Prentice Hall

Cross, Nigel. 2001. Engineering Design Methods: Strategies for Product Design. New York: John Wiley Publishing.

Nurmianto, Eko. 1991. Ergonomi Konsep Dasar dan Aplikasinya. Jakarta: Guna Widya.

Purnomo, Hari. 2004. Pengantar Teknik Industri. Cet. I; Yogyakarta: Graha Ilmu.

Sinulingga Sukaria, 2008. Pengantar Teknik Industri. Yogyakarta: Graha Ilmu. 